\title{
Equations for the Prediction of Normal Values for Exchangeable Sodium, Exchangeable Potassium, Extracellular Fluid Volume, and Total Body Water
}

Despite the valuable research information on body electrolytes and water that is gained from isotope dilution studies, these investigations have not become routine clinical procedure. This is partly due to the fact that normal ranges for exchangeable sodium $\left(\mathrm{Na}_{\mathrm{E}}\right)$, exchangeable potassium $\left(\mathrm{K}_{\mathrm{E}}\right)$, extracellular fluid volume (E.C.F.V.), and total body water (T.B.W.) are wide owing to great individual variations in body fat content, so that it is difficult to differentiate normal from disease states. ${ }^{12}$ Also, equations for the prediction of normal values at present available from the literature are based on limited numbers of subjects investigated from single laboratories.

Medizinische Universitatsklinik, Innsbruck, Austria

F. SKRABAL, DR. MED., Hochschulassistent

Hammersmith Hospital, London W12 0HS

R. N. ARNOT, B.SC., Senior Physicist

G. F. JOPLIN, PH.D., F.R.C.P., Consultant Physician, Endocrine Unit.

\section{Present Calculations}

Since the relation of height to weight gives an index of obesity we have calculated equations for the prediction in both sexes of $\mathrm{Na}_{\mathrm{E}}, \mathrm{K}_{\mathrm{E}}$, E.C.F.V. (as measured with bromide), and T.B.W. (as measured with tritiated water, deuterium oxide, or antipyrine) from body weight, height, and age using published data where adequate details were available, ${ }^{3-21}$ and our own results, using simultaneously ${ }^{24} \mathrm{Na},{ }^{43} \mathrm{~K},{ }^{77} \mathrm{Br}$, and ${ }^{3} \mathrm{H}_{2} \mathrm{O} .{ }^{22}$ Data about which there may be some doubt were excluded-for example, lack of correlation between $K_{E}$ and 24-hour urinary creatinine excretion. ${ }^{23}$

The equations which we have obtained are shown in the table. They should be generally applicable since the data have been obtained from several laboratories.

Although it is generally accepted that $\mathrm{K}_{\mathrm{E}}$ should be measured after a 40-hour equilibration period, at least half of the reported normal values are based on measurements after 24 hours' equilibration. In the equations in the table, data using both periods have been pooled. The error produced should be small since the slope of the equilibration curve of radioactive potassium between 24 and 40 hours in subjects on a potassium-free intake is small. ${ }^{24}$

Very few workers have measured $\mathrm{Na}_{\mathrm{E}}, \mathrm{K}_{\mathrm{E}}$, E.C.F.V., and T.B.W. simultaneously although in many instances a complete

Prediction of Normal Values for Exchangeable Sodium $\left(N a_{\mathrm{E}}\right)$, Exchangeable Potassium $\left(K_{\mathrm{E}}\right)$, Extracellular Fluid Volume (E.C.F.V.), and Total Body Water (T.B.W. from Weight, Height, Age, and Sex*

\begin{tabular}{|c|c|c|c|c|c|c|c|c|c|c|}
\hline & \multirow[t]{2}{*}{ Pool/Compartment } & \multirow{2}{*}{$\begin{array}{c}\text { Weight } \\
(\mathbf{k g})\end{array}$} & \multirow{2}{*}{$\begin{array}{c}\text { Height } \\
(\mathrm{cm})\end{array}$} & \multirow{2}{*}{$\begin{array}{c}\text { Age } \\
\text { (years) }\end{array}$} & \multirow{2}{*}{$\begin{array}{c}\text { Mean } \\
\begin{array}{c}\text { Experimental } \\
\text { Value }\end{array}\end{array}$} & \multirow{2}{*}{$\begin{array}{l}\text { S.D. of } \\
\text { Predicted } \\
\text { Value }\end{array}$} & \multicolumn{4}{|c|}{$\begin{array}{l}\text { Normal Subjects Studied } \\
\text { Mean (range) }\end{array}$} \\
\hline & & & & & & & No. & Weight (kg) & Height $(\mathrm{cm})$ & Age (years) \\
\hline \multirow{7}{*}{$\sum^{\sharp \pi}$} & $\underset{(\mathrm{mEq})}{\mathrm{NaE}}$ & $=\quad \begin{array}{l}14.2 \\
r=0.54 \dagger\end{array}$ & $+\quad \begin{array}{r}16 \cdot 2 \\
r=0.48 \dagger\end{array}$ & $-\quad \stackrel{2.6}{r=-0.24 \ddagger}-800$ & $r \stackrel{3,009}{=0.63 \dagger}$ & \pm 296 & 82 & $\begin{array}{c}73 \cdot 8 \\
(50 \cdot 7-100 \cdot 5) \\
\end{array}$ & $\begin{array}{c}175 \cdot 8 \\
(159-193) \\
\end{array}$ & $\begin{array}{c}29 \cdot 6 \\
(18-74) \\
\end{array}$ \\
\hline & $\begin{array}{c}\mathrm{K} \\
(\mathrm{mEq})\end{array}$ & $=\quad \begin{aligned} 23.0 \\
\mathrm{r}=0.61 \dagger\end{aligned}$ & $+\quad \begin{array}{l}20.6 \\
\mathrm{r}=0.61 \dagger\end{array}$ & $-\underset{r=-0.43 \dagger}{12 \cdot 0}-1,574$ & $r \stackrel{3,335}{=0.78 \dagger}$ & \pm 354 & 151 & $\begin{array}{c}73 \cdot 0 \\
(50 \cdot 0-125 \cdot 5)\end{array}$ & $\begin{array}{c}175.4 \\
(162-198)\end{array}$ & $\begin{array}{l}31.8 \\
(18-75) \\
\end{array}$ \\
\hline & $\underset{\text { (ml) }}{\text { E.C.F.V. }}$ & $=\quad \begin{array}{l}99.5 \\
r=0.63 \dagger\end{array}$ & $+\quad \begin{array}{l}197.8 \\
r=0.73 \dagger\end{array}$ & $r=-0.07(\mathrm{~N} . \mathrm{S} .)^{-23.670}$ & $\begin{array}{l}17,685 \\
\mathrm{r}=0.87 \dagger\end{array}$ & $\pm 1,160$ & 54 & $\begin{array}{c}68 \cdot 9 \\
(47 \cdot 7-100 \cdot 5)\end{array}$ & $\begin{array}{c}174 \cdot 4 \\
(157-186)\end{array}$ & $\begin{array}{c}30.2 \\
(18-58)\end{array}$ \\
\hline & $\begin{array}{l}\text { T.B.W. (T.W. and D.O.) } \\
\text { (ml) }\end{array}$ & $=\begin{array}{l}342 \cdot 1 \\
r=0.71 \dagger\end{array}$ & $+\quad \begin{array}{l}161.5 \\
\mathrm{r}=0.52 \dagger\end{array}$ & $-{ }_{r=}^{132 \cdot 0}-0.30 \dagger-6,589$ & $\begin{array}{l}42,240 \\
r=0.80 \dagger\end{array}$ & $\pm 3,165$ & 143 & $\begin{array}{c}71 \cdot 9 \\
(50 \cdot 0-100 \cdot 3) \\
\end{array}$ & $\begin{array}{c}176-0 \\
(159-196)\end{array}$ & $\begin{array}{c}31 \cdot 9 \\
(17-86)\end{array}$ \\
\hline & $\underset{\text { T.Bl) }}{\text { T.P.W.(A.P.) }}$ & $=\quad \begin{array}{l}249.4 \\
r=0.70 \dagger\end{array}$ & $+\begin{array}{l}303.3 \\
r=0.68 \dagger\end{array}$ & $-{ }_{r=-0.26 \S^{25.9}}-29,690$ & $\begin{array}{l}41,830 \\
r=0.79 \dagger\end{array}$ & $\pm 3,790$ & 50 & $\begin{array}{c}76 \cdot 4 \\
(51 \cdot 3-122 \cdot 8)\end{array}$ & $\begin{array}{c}175 \cdot 8 \\
(160-188)\end{array}$ & $\begin{array}{c}30 \cdot 3 \\
(22-60)\end{array}$ \\
\hline & T.B.W. (combined) & $\begin{aligned} &= 300.6 \\
& r=0.67 \dagger\end{aligned}$ & $+\begin{array}{l}198.8 \\
\mathbf{r}=0.57 \dagger\end{array}$ & $-{ }_{\mathrm{r}=-0.29 \dagger}^{109 \cdot 3}-11,310$ & $\begin{array}{l}42,130 \\
r=0.78 \dagger\end{array}$ & $\pm 3,425$ & 193 & $\begin{array}{c}73 \cdot 1 \\
(50 \cdot 0-122 \cdot 8) \\
\end{array}$ & $\begin{array}{c}175.9 \\
(159-196)\end{array}$ & $\begin{array}{c}32 \cdot 1 \\
(17-86)\end{array}$ \\
\hline & $\underset{(\mathrm{mEq})}{\mathrm{NaE}+\mathrm{K}_{\mathrm{E}}}$ & $=\quad \begin{array}{l}39.6 \\
r=0.62 \dagger\end{array}$ & $+\quad \begin{array}{r}46.2 \\
r=0.45 \dagger\end{array}$ & $-\quad \stackrel{28 \cdot 7}{r=0.268}-3,872$ & $r \stackrel{6,223}{=0.76+}$ & \pm 450 & 42 & $\begin{array}{c}71 \cdot 8 \\
(56 \cdot 5-100 \cdot 5)\end{array}$ & $\begin{array}{c}174 \cdot 8 \\
(163-184)\end{array}$ & $\begin{array}{c}28 \cdot 6 \\
(18-48)\end{array}$ \\
\hline \multirow{5}{*}{ 总 } & $\begin{array}{c}\mathrm{NaE} \\
(\mathrm{mEq})\end{array}$ & $=\begin{array}{l}17.9 \\
r=0.54 \dagger\end{array}$ & $+\quad \begin{array}{r}5.2 \\
\mathrm{r}=0.45 \dagger\end{array}$ & $\mathrm{r}=0.12$ (N.S.) & $\mathbf{2 , 4 2 6}=0.80 \dagger$ & \pm 235 & 99 & $\begin{array}{c}64 \cdot 0 \\
(41 \cdot 8-130 \cdot 0) \\
\end{array}$ & $\begin{array}{c}157 \cdot 7 \\
(140-180) \\
\end{array}$ & $\begin{array}{c}39 \cdot 5 \\
(16-72) \\
\end{array}$ \\
\hline & $\underset{(\mathbf{m E q})}{\mathrm{K}_{\mathrm{E}}}$ & $=\quad \begin{array}{c}15.3 \\
\mathrm{r}=0.56 \dagger\end{array}$ & $+\quad \begin{array}{l}3.9 \\
r=0.32 \dagger\end{array}$ & $-{ }_{r=-0.48 \dagger}^{12 \cdot 6}+1,197$ & $\mathrm{r} \stackrel{2,275}{=0.78+}$ & \pm 267 & 136 & $\begin{array}{c}64 \cdot 8 \\
(41 \cdot 8-130 \cdot 0)\end{array}$ & $\begin{array}{c}158 \cdot 4 \\
(140-180)\end{array}$ & $\begin{array}{c}41 \cdot 9 \\
(16-81)\end{array}$ \\
\hline & $\underset{\text { (ml) }}{\text { E.C.F.V. }}$ & 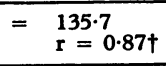 & $+\begin{array}{r}76.1 \\
r=0.22 \S \\
\end{array}$ & $\mathrm{r}=0.09$ (N.S.) ${ }^{5,960}$ & $\begin{array}{l}17,430 \\
r=0.88 \dagger\end{array}$ & $\pm 2,011$ & 55 & $\begin{array}{c}80 \cdot 2 \\
(41 \cdot 8-130 \cdot 0)\end{array}$ & $\begin{array}{c}164 \cdot 4 \\
(140-179)\end{array}$ & $\begin{array}{c}33 \cdot 2 \\
(17-68)\end{array}$ \\
\hline & T.B.W.(T.W. and D.O.) & $=\begin{array}{l}230.5 \\
r=0.92 \dagger\end{array}$ & $+\quad \begin{array}{l}203.7 \\
r=0.39 \dagger\end{array}$ & $\mathrm{r}=-0.05$ (N.S.) & $\begin{array}{l}32,930 \\
r=0.94 \dagger\end{array}$ & $\pm 2,143$ & 85 & $\begin{array}{c}71 \cdot 9 \\
(41 \cdot 8-132 \cdot 0) \\
\end{array}$ & $\begin{array}{c}165.4 \\
(151-180) \\
\end{array}$ & $\begin{array}{c}32 \cdot 9 \\
(17-72)\end{array}$ \\
\hline & $\underset{(\mathrm{mEq})}{\mathrm{NaE}+\mathrm{K}_{E}}$ & $=\quad \begin{aligned} 31.7 \\
r=0.79 \dagger\end{aligned}$ & $+\quad \begin{array}{r}14.7 \\
r=0.35 \dagger\end{array}$ & $\mathrm{r}=-0.15\left(\mathrm{~N}^{+} . \mathrm{S} .\right)^{413}$ & $\stackrel{4,761}{=0.80 \dagger}$ & $\pm \mathbf{4 4 8}$ & 90 & $\frac{64 \cdot 0}{(42 \cdot 1-130 \cdot 0)}$ & $\begin{array}{c}157 \cdot 3 \\
(140-190)\end{array}$ & $\begin{array}{c}39 \cdot 5 \\
(17-32)\end{array}$ \\
\hline
\end{tabular}

* To obtain the predicted normal value for a pool/compartment for a given patient, multiply his/her weight, height, and age by the above factors and complete the equation. The values give the correlation between weight, height, age, or predicted value, with the experimental value, for the pool/compartmeht.

$+\mathbf{P}<0.001$.

$+\mathbf{P}<0.05$.

T.W. $=$ Tritiated water. D.O. = Deuterium oxide. A.P. = Antipyrine, (comprehensive antipyrine data on females are not available). N.S. $=$ Not significant. 
picture of the electrolyte status would have been of great interest. This is certainly attributable to the time consuming procedures required to separate the commonly used isotopes. The use of the cyclotron-produced ${ }^{43} \mathrm{~K}$ and ${ }^{77} \mathrm{Br}$ with ${ }^{24} \mathrm{Na}$ greatly facilitates the simultaneous measurements of $\mathrm{K}_{\mathrm{E}}, \mathrm{E}$.C.F.V., and $\mathrm{Na}_{\mathrm{E}}$ but beta counting of ${ }^{3} \mathrm{H}_{2} \mathrm{O}$ must be carried out after decay of the gamma emitters to measure T.B.W. Further work on the development of a radiochemically stable iodoantipyrine and on the distribution space and metabolism in man of this substance may be worth while. In-vitro instability has been shown in some presently available products, ${ }^{25}$ and in-vivo instability has been shown in some species, ${ }^{26}$ although this effect was found to be small in man. ${ }^{27}$ Should iodoantipyrine be suitable for T.B.W. measurement, a stable product labelled with ${ }^{125} \mathrm{I}$ or ${ }^{123} \mathrm{I}$ would be desirable for use with ${ }^{24} \mathrm{Na},{ }^{43} \mathrm{~K}$, and ${ }^{77} \mathrm{Br}$, since the gamma energy of either isotope would permit the estimation of T.B.W. with $\mathrm{Na}_{\mathrm{E}}, \mathrm{K}_{\mathrm{E}}$, and E.C.F.V. by counting untreated plasma and urine samples on a multichannel gamma spectrometer.

Although the use of the above equations and the measurement technique developed by us $^{22}$ should enable a more widespread application of the isotope dilution method, the confidence limits of the prediction are wide, and thus limit the immediate value for diagnosis. Perhaps the additional use of simple indices of body fat content such as multiple skinfold measurements would help in narrowing the confidence limits of the predicted normal range.

\section{References}

${ }^{1}$ Edelmann, I. S., and Leibman, J., American fournal of Medicine, 1959, 195,256

${ }^{2}$ Lancet, 1971, 1, 1282.
${ }^{3}$ Corsa, L., Olney, J. M., Steenburg, R. W., Ball, M. R., and Moore, F. D., fournal of Clinical Investigation, 1950, 29, 1280.

Schloerb, P. R., Friis-Hansen, B. J., Edelman, I. S., Solomon, A. K., and Moore, F. D., Fournal of Clinical Investigation, 1950, 29, 1296.

5 Forbes, G. B., and Perley, A., Fournal of Clinical Investigation, 1951, 30,

- Deane, N., and Smith, H. W., fournal of Clinical Investigation, 1952, 31, 197.

' Deane, N., Ziff, M., and Smith, H. W., fournal of Clinical Investigation, $1952,31,200$.

${ }^{8}$ Edelman, I. S., et al., Surgery, Gynecology and Obstetrics, 1952, 31, 412.

9 Prentice, T. C. et al., Fournal of Clinical Investigation, 1952, 31, 412.

${ }^{10}$ Arons, W. L., Vanderlinde, R. J., and Solomon, A. K., fournal of Clinical Investigation, 1954, 33, 1001.

11 Ikkos, D., Luft, R., and Sjögren, B., Metabolism: Clinical and Experimental,

1954, 3, 400.
12 Ikkos, D., Lunnggren, H., Luft, R., and Sjögren, B. Metabolism: Clinical and Experimental, 155, 4, 231.

13 Sagild, U., Scandinavian fournal of Clinical and Laboratory Investigation, $1956,8,44$.

${ }^{14}$ Ljunggren, H., Ikkos, D., and Luft, R., Acta Endocrinologica (Kobenhavn), $1957,25,187$.

15 Ljunggren, H., Ikkos, D., and Luft, R., Acta Endocrinologica (Kobenhavn), $1957,25,199$.

${ }^{16}$ Muldowney, F. P., Crooks, J., and Bluhm, M. M., fournal of Clinical Investigation, 1957, 36, 1375 .

17 Cooper, J. A. D., Revdin, N. S., and Borden, C. J., Fournal of Laboratory and Clinical Medicine, 1958, 52, 129.

18 Crooks, J., Bluhm, M. M., and Muldowney, F. P., Clinical Science, 1960, 18, 175.

10 Macgilivray, I., Buchanan, T. J., and Billewicz, W. Z., Clinical Science, $1960,19,17$.

20 Talso, P. J., Miller, C. E., Carballo, A. J., and Vasquez, I., Metabolism: Clinical and Experimental, 1960, 9, 456.

${ }^{21}$ Nicholson, J. P., and Silva, J. F., Clinical Science, 1964, 27, 97.

22 Skrabal, F., Arnot, R. N., Helus, F., Glass, H. I., and Joplin, G. F., International Fournal of Applied Radiation and Isotopes, 1970, 21,183 .

${ }^{3}$ Aikawa, J. K., Harrell, G. T., and Eisenberg, B., Fournal of Clinical Investigation, 1952, 31, 367.

24 Johnson, J. E., Hartsuck, J. M., Zollinger, R. M., Moore, F. D., Metabolism: Clinical and Experimental, 1969, 18, 663.

25 Munck, O., and Andersen, A. M., Scandinavian fournal of Clinical and Laboratory Investigation, 1967, 19, 256.

26 Sullivan, J. M., and Rose, J. C., fournal of Laboratory and Clinical Medicine, 1961, 57, 955 .

${ }^{27}$ Reinmuth, O. M., Scheinberg, P., and Bourne, B., Archives of Neurology, $1965,12,49$.

\title{
Thalassaemia in Cyprus
}

\author{
TH. ASHIOTIS, Z. ZACHARIADIS, K. SOFRONIADOU, D. LOUKOPOULOS, \\ G. STAMATOYANNOPOULOS
}

British Medical fournal, 1973, 2, 38-41

\section{Summary}

Frequencies of the thalassaemias in Cyprus were examined by a survey of hospital inpatients and haematological investi-

Central Laboratory, Nicosia General Hospital, Nicosia, Cyprus TH. ASHIOTIS, Chief Technologist

Z. ZACHARIADIS, Technologist

Division of Medical Genetics, University of Washington School of Medicine, Seattle, Washington 98195 U.S.A.

K. SOFRONIADOU, M.D., Research Fellow

G. STAMATOYANNOPOULOS, M.D., Associate Professor,

First Department of Medicine, University of Athens Medical School, Goudi, Athens, Greece

D. LOUKOPOULOS, M.D., Instructor gations of adult and newborn population samples. The data indicate that $15 \%$ of the Greek and Turkish Cypriots are carriers of beta-thalassaemia genes, while $10 \%$ of the population carry alpha-thalassaemia genes. These are the highest frequencies of thalassaemia genes found today in any Caucasian population.

\section{Introduction}

Population genetic studies in areas where thalassaemias are common in addition to their theoretical interest are of much practical importance. In planning management facilities a consideration of the types and frequencies of the various thalassaemia genes in the population is necessary because the public health problems created by the various forms of thalassaemia differ. Information about the frequency of thalassaemia types in a population is also instrumental to the design of preventive 